\title{
Crude glycerin is an efficient alternative to corn in the diet of feedlot lambs
}

\author{
Fernada Almeida Merlim ${ }^{1}$, Américo Garcia Silva Sobrinho ${ }^{1}$, Thiago Henrique Borghi ${ }^{1}$, \\ Luís Gabriel Alves Cirne ${ }^{2}$, Roberta Lima Valença ${ }^{1}$, Fabiana Alves Almeida ${ }^{1}$, Viviane Endo ${ }^{1}$, \\ Carlos Renato Viegas ${ }^{1}$, and Nivea Maria Brancacci Lopes Zeola ${ }^{1}$ \\ ${ }^{1}$ Department of Animal Science, São Paulo State University, Jaboticabal, São Paulo, 14884-900, Brazil \\ ${ }^{2}$ Institute of Biodiversity and Forestry, Federal University of Western Pará, \\ Santarém, Pará, 68035-110, Brazil
}

Correspondence: Fabiana Alves Almeida (faalvesalmeida@yahoo.com.br)

Received: 3 November 2020 - Revised: 9 August 2021 - Accepted: 19 August 2021 - Published: 17 September 2021

\begin{abstract}
The objective of this study was to evaluate the intake, digestibility, nitrogen balance, and performance of feedlot lambs fed diets containing crude glycerin. A total of 30 Ile de France lambs were confined to individual pens at an average age of $45 \mathrm{~d}: 15.1 \mathrm{~kg}$ initial body weight and $32.2 \mathrm{~kg}$ final body weight. The animals were distributed in a completely randomized design and fed three diets containing fresh sugarcane as forage (50\%) and concentrate $(50 \%)$, with or without the inclusion of 100 and $200 \mathrm{~g}$ vegetable crude glycerin per kilogram dry matter (DM) replacing corn. Dietary glycerin inclusion reduced the intake of ether extract $(P<0.001)$ and total carbohydrates $(P=0.048)$ as well as the apparent digestibility of ether extract $(P<0.001)$, but it had no effect on the intake and digestibility of the other nutrients nor on lamb performance. The apparent nitrogen balance of lambs on the three diets was positive. Although it does not affect the intake and digestibility of most nutrients, the inclusion of 100 and $200 \mathrm{~g} \mathrm{~kg}^{-1} \mathrm{DM}$ of crude glycerin in the diet tends to worsen lamb performance, indicating that the ideal level of inclusion should be below $100 \mathrm{~g} \mathrm{~kg}^{-1} \mathrm{DM}$ of crude glycerin.
\end{abstract}

\section{Introduction}

In view of the increasing worldwide demand for animal protein, including sheep meat, animals need to be produced on a large enough scale to meet the requirements of the consumer market. Nutrition plays a fundamental role in animal production. In this respect, nutritional strategies should be adopted to incorporate waste and by-products of agricultural industries into the feed base of ruminants in order to reduce the use of grains in animal feed, thereby leaving them for human consumption. Moreover, in the current economic scenario, grains have reached high prices, rendering diets more expensive and increasing the costs of animal production. For this reason, by-products of the biodiesel industry, such as vegetable crude glycerin, have been studied for use in place of traditional feed ingredients (Gunn et al., 2010; Lage et al., 2010).

The inclusion of crude glycerin in diet formulations provides a gluconeogenic substrate for ruminants, as these an- imals use the glycerol in dietary glycerin to form glucose (Krehbiel, 2008). In this way, this feedstuff can partially replace starchy feedstuffs in diets, especially cereal grains such as corn. However, optimal replacement formulations are yet to be established.

Gunn et al. (2010) evaluated the effects of up to $450 \mathrm{~g} \mathrm{~kg}^{-1}$ crude glycerin in dry matter (DM) on lamb fatness and found that the inclusion of $150 \mathrm{~g} \mathrm{~kg}^{-1}$ glycerin in the diet did not compromise animal performance. Lage et al. (2010) observed decreased performance in lambs fed up to $120 \mathrm{~g} \mathrm{~kg}^{-1}$ crude glycerin in DM. Oliveira Filho et al. (2016) studied the inclusion of up to $108 \mathrm{~g} \mathrm{~kg}^{-1}$ crude glycerin in DM of sugarcane silage and found no changes in intake, digestibility, or nitrogen balance in lambs. Ribeiro et al. (2018) evaluated the use of up to $210 \mathrm{~g} \mathrm{~kg}^{-1}$ crude glycerin in DM in lamb diets and reported that the inclusion of $47 \mathrm{~g} \mathrm{~kg}^{-1}$ of the ingredient provided the greatest increase in body growth. 
Sugarcane is one of the most commonly used forages by farmers due to characteristics such as high yield potential and lower production costs. Thus, the present study was motivated by the fact that no studies have examined the performance of lambs fed diets containing crude glycerin as a substitute for corn and using fresh sugarcane as the roughage component. In this context, this study investigates the effects of replacing dietary corn with two concentrations of glycerin on the intake, digestibility, nitrogen balance, and performance of feedlot lambs.

\section{Material and methods}

\subsection{Location and ethical considerations}

The experiment was conducted in the city of Jaboticabal, state of São Paulo, Brazil $\left(21^{\circ} 14^{\prime} 05^{\prime \prime} \mathrm{S}, 48^{\circ} 17^{\prime} 09^{\prime \prime} \mathrm{W}\right.$; 615.01 ma.s.l.; atmospheric pressure of $944.3 \mathrm{hPa}$; average temperature of $22.2{ }^{\circ} \mathrm{C}$; relative humidity of $72.5 \%$; precipitation of $1453.4 \mathrm{~mm}$ ), following the guidelines set by the Ethics Committee on Animal Use (approval no. 005962/12).

\subsection{Animals, experimental design, and diets}

A total of 30 newly weaned $45 \mathrm{~d}$ old uncastrated male Ile de France lambs with a body weight of $15 \pm 0.2 \mathrm{~kg}$ were individually identified, dewormed, and housed in individual $1.0 \mathrm{~m}^{2}$ pens in a shed with a suspended slatted floor, equipped with feeders and drinkers. A total of 10 lambs were randomly allocated to each of the three dietary treatments.

The tested diets were formulated with or without the inclusion of vegetable crude glycerin at 100 or $200 \mathrm{~g} \mathrm{~kg}^{-1} \mathrm{DM}$ replacing corn (Tables 1,2). Sugarcane variety IAC 86-2480 (developed by the Agronomic Institute of Campinas, Brazil, for use in animal feed due to the low amount of fiber compared with other varieties) was chopped into $1.0 \mathrm{~cm}$ particles and supplied fresh. The glycerin from soybean oil $(83.90 \%$ glycerol, $12.31 \%$ moisture, and $3.79 \%$ salts) was weighed and mixed with the concentrate at the time the diets were supplied to the lambs. The resulting diets had similar protein $(16 \%)$ and energy (3.35 Mcal kg ${ }^{-1} \mathrm{DM}$ metabolizable energy) contents and were prepared as recommended by the National Research Council (NRC, 2007) requirements for weaned lambs, for an estimated $250 \mathrm{~g} \mathrm{~d}^{-1}$ weight gain. The roughage: concentrate ratio was $50: 50$, and the diets were provided ad libitum (at least 10\% leftovers) at 07:00 and 17:00 h.

\subsection{Chemical analysis}

The chemical composition of the diets (Table 1) is presented in grams per kilogram of dry matter $\left(\mathrm{g} \mathrm{kg}^{-1} \mathrm{DM}\right)$ and was determined after oven-drying at $65^{\circ} \mathrm{C}$ for $24 \mathrm{~h}$ and milling through a $1.0 \mathrm{~mm}$ screen (AOAC, 1998; ID 934.01). Mineral matter $(\mathrm{MM})$ was measured after combustion at $550^{\circ} \mathrm{C}$
Table 1. Ingredients and chemical composition of experimental diets.

\begin{tabular}{lrrr}
\hline Composition & \multicolumn{3}{c}{$\begin{array}{c}\text { Crude glycerin } \\
\left(\mathrm{g} \mathrm{kg}^{-1} \mathrm{DM}\right)\end{array}$} \\
\cline { 2 - 4 } & 0 & 100 & 200 \\
\hline Ingredient proportions $\left(\mathrm{g} \mathrm{kg}^{-1} \mathrm{DM}\right)$ & & \\
\hline Sugarcane & 500.0 & 500.0 & 500.0 \\
Crude glycerin & 0.0 & 100.0 & 200.0 \\
Corn grain, ground, dry & 254.3 & 136.9 & 10.4 \\
Soybean meal & 217.7 & 240.0 & 265.5 \\
Dicalcium phosphate & 2.8 & 2.2 & 1.8 \\
Calcium carbonate & 5.7 & 4.3 & 3.3 \\
Mineral-vitamin supplement & \\
Urea & 9.5 & 9.5 & 9.5 \\
\hline Chemical composition $(\mathrm{g} \mathrm{kg}$ & 10.0 & 10.0 & 10.0 \\
\hline Dry matter $\left(\mathrm{g} \mathrm{kg}{ }^{-1}\right.$ as fed) & 381.7 & 359.6 & 345.8 \\
Mineral matter & 53.4 & 67.2 & 81.7 \\
Crude protein & 165.3 & 167.4 & 169.0 \\
Ether extract & 19.6 & 11.0 & 6.3 \\
Neutral detergent fiber & 293.7 & 295.3 & 290.4 \\
Acid detergent fiber & 123.4 & 131.7 & 120.5 \\
Total carbohydrates & 788.7 & 759.8 & 721.1 \\
Nonfibrous carbohydrates & 563.5 & 528.1 & 517.4 \\
Gross energy (Mcal kg $\left.{ }^{-1} \mathrm{DM}^{\mathrm{a}}\right)$ & 3.88 & 3.99 & 3.72 \\
\hline
\end{tabular}

${ }^{\mathrm{a}}$ Guaranteed levels per kilogram of product: $120 \mathrm{~g} \mathrm{Ca}, 90 \mathrm{~g} \mathrm{Cl}, 62 \mathrm{~g} \mathrm{Na}$, $54 \mathrm{~g} \mathrm{Mg}, 50 \mathrm{~g} \mathrm{P}, 34 \mathrm{~g} \mathrm{~S}, 1600 \mathrm{mg} \mathrm{Zn}, 1500 \mathrm{mg} \mathrm{Mn}, 1064 \mathrm{mg} \mathrm{Fe}, 730 \mathrm{mg} \mathrm{F}$ (Max), $50 \mathrm{mg} \mathrm{Cu}, 25 \mathrm{mg} \mathrm{I}, 20 \mathrm{mg} \mathrm{Se}, 10 \mathrm{mg}$ Co, $100000 \mathrm{IU}$ vitamin A, $40000 \mathrm{IU}$ vitamin $\mathrm{D} 3$, and $600 \mathrm{IU}$ vitamin $\mathrm{E}$.

for $16 \mathrm{~h}($ AOAC, 1998; ID 942.05). The nitrogen (N) concentration was obtained using the Kjeldahl method (AOAC, 1998; ID 988.05); crude protein (CP) was calculated as the $\mathrm{N}$ content multiplied by the factor 6.25 ; and the ether extract (EE) content was obtained using method ID 920.39 (AOAC, 1998). Neutral detergent fiber (NDF) and acid detergent fiber (ADF) contents were measured according to the recommendations of Van Soest (1994): using bags (F57) and the ANKOM 200 device (ANKOM Technology Corp., Fairport, NY, USA) with heat-stable $\alpha$-amylase. Total carbohydrates (TC) were estimated by following the procedure of Sniffen et al. (1992). Nonfibrous carbohydrates (NFC) were calculated as the difference between TC and NDF (Sniffen et al., 1992). Gross energy (GE) was obtained by sample combustion in an adiabatic bomb calorimeter (PARR Instruments). Lipid extraction was performed as described by Bligh and Dyer (1959) to determine the fatty acid profile. The extracted lipids were converted to fatty acid methyl esters following the technique of Hartman and Lago (1973) and were analyzed using a Shimadzu 14B gas chromatograph equipped with a flame ionization detector and fused silica capillary column (OMEGAWAX250, size: $30 \mathrm{~m} \times 0.25 \mathrm{~mm} \times 0.25 \mu \mathrm{m}$, cat. no. 24136 Supelco). The injector and detector temperatures were 250 and $280^{\circ} \mathrm{C}$, respectively, and the helium flow ratio was 
Table 2. Percentage composition of fatty acids in diets.

\begin{tabular}{|c|c|c|c|}
\hline \multirow[t]{2}{*}{ Fatty acid (\%) } & \multicolumn{3}{|c|}{$\begin{array}{l}\text { Crude glycerin } \\
\left(\mathrm{g} \mathrm{kg}^{-1} \mathrm{DM}\right)\end{array}$} \\
\hline & 0 & 100 & 200 \\
\hline \multicolumn{4}{|l|}{ Saturated } \\
\hline Capric (C10:0) & 0.04 & 0.03 & 0.03 \\
\hline Lauric (C12:0) & 0.11 & 0.10 & 0.17 \\
\hline Myristic (C14:0) & 0.26 & 0.23 & 0.39 \\
\hline Pentadecanoic (C15 : 0) & 0.11 & 0.07 & 0.10 \\
\hline Palmitic (C16:0) & 17.21 & 19.08 & 22.98 \\
\hline Margaric (C17:0) & 0.20 & 0.15 & 0.20 \\
\hline Stearic $(\mathrm{C} 18: 0)$ & 4.36 & 4.68 & 4.27 \\
\hline Arachidic (C20:0) & 0.87 & 0.77 & 0.73 \\
\hline Behenic $(\mathrm{C} 22: 0)$ & 0.35 & 0.38 & 0.49 \\
\hline Tricosanoic (C23:0) & 0.14 & 0.14 & 0.15 \\
\hline Lignoceric (C24 : 0) & 0.60 & 0.54 & 0.54 \\
\hline \multicolumn{4}{|l|}{ Monounsaturated } \\
\hline Palmitoleic (C16: 1) & 1.40 & 1.87 & 0.91 \\
\hline Heptadecenoic (C17 : 1) & 0.07 & 0.08 & 0.11 \\
\hline Oleic $(\mathrm{C} 18: 1 \omega 9)$ & 31.61 & 31.19 & 30.10 \\
\hline Cis-vaccenic (C18: $1 \omega 7)$ & 0.98 & 0.88 & 0.93 \\
\hline Eicosenoic $(\mathrm{C} 20: 1 \omega 9)$ & 0.39 & 0.37 & 0.38 \\
\hline \multicolumn{4}{|l|}{ Polyunsaturated } \\
\hline Linoleic $(\mathrm{C} 18: 2 \omega 6)$ & 38.82 & 36.65 & 35.07 \\
\hline$\alpha$-Linolenic $(\mathrm{C} 18: 3 \omega 3)$ & 2.19 & 2.56 & 2.18 \\
\hline$\gamma$-Linolenic $(\mathrm{C} 18: 3 \omega 6)$ & 0.04 & 0.04 & 0.03 \\
\hline Eicosadienoic (C20:2) & 0.21 & 0.16 & 0.21 \\
\hline Eicosatrienoic $(\mathrm{C} 20: 3 \omega 6)$ & 0.04 & 0.03 & 0.03 \\
\hline Omega- $3^{\mathrm{a}}(\omega 3)$ & 2.19 & 2.56 & 2.18 \\
\hline Omega- $6^{\mathrm{b}}(\omega 6)$ & 38.90 & 39.72 & 35.13 \\
\hline Omega-6:Omega-3 ( $\omega 6: \omega 3)$ & 17.76 & 15.51 & 16.11 \\
\hline
\end{tabular}

$1 \mathrm{~mL} \mathrm{~min}^{-1}$. After injection $(1 \mu \mathrm{L})$, the column temperature was held at $100^{\circ} \mathrm{C}$ for $2 \mathrm{~min}$ and then increased to $220^{\circ} \mathrm{C}$ at $4{ }^{\circ} \mathrm{Cmin}^{-1}$. Following this, the temperature was kept at $220^{\circ} \mathrm{C}$ for $25 \mathrm{~min}$. The peaks were identified by comparing retention times with the standards for fatty acid methyl esters from Sigma.

\subsection{Intake, apparent nutrient digestibility, and nitrogen balance}

Leftovers were collected and weighed daily before the morning feeding to determine dry matter intake and adjust the feed supply. The intake of nutritional components was estimated by calculating the difference between the total of each nutrient contained in the feed offered to the lambs and the total of each nutrient in the leftovers.

A total of $45 \mathrm{~d}$ after the beginning of the performance trial, the digestibility trial was started using 15 lambs (5 in each treatment; the choice of lambs was random) from the same 30 lambs, with an average body weight of $23 \mathrm{~kg}$ (Endo et al., 2015). The lambs were placed in metabolic cages that allowed for the separate collection of feces and urine, where they remained for $7 \mathrm{~d}$ of adaptation followed by $5 \mathrm{~d}$ of total feces and urine collection. The experiment was laid out in a completely randomized design with three treatments and five replicates. After this period, the lambs returned to the performance trial in the feedlot.

Feces were collected in plastic basins, and urine was collected in plastic buckets containing $100 \mathrm{~mL}$ of $20 \%$ sulfuric acid solution $\left(\mathrm{H}_{2} \mathrm{SO}_{4}\right)$ to acidify it and avoid ammonia loss by volatilization; this volume was later deducted from the total daily urine volume. Plastic buckets were cut in a bevel shape and covered with fine mesh so that the feces falling on the screen would slide into the bowl and be separated from the urine. Ten percent of the feces and urine was sampled and stored at $-18^{\circ} \mathrm{C}$ daily, and the samples were used to form one composite sample per lamb at the end of the digestibility trial.

Apparent nutrient digestibility (AND) was calculated using the following equation: $A N D=[$ (kilograms of the portion ingested-kilograms of the portion excreted)/(kilograms of the portion ingested) $] \times 100$.

Apparent nitrogen balance (ANB) was calculated using the following formulae: $\mathrm{ANB}$ or $N_{\text {retained }}=N_{\text {intake }}-$ $\left(N_{\text {feces }}+N_{\text {urine }}\right) ; N_{\text {absorbed }}=N_{\text {intake }}-N_{\text {feces }} ;$ and $N_{\text {intake }}=$ $N_{\text {supplied }}-N_{\text {orts }}$, and expressed in grams per day $\left(\mathrm{g} \mathrm{d}^{-1}\right)$ and in grams per metabolic weight per day.

\subsection{Performance}

Feed conversion was calculated as the ratio between DM intake $(\mathrm{kg})$ and average weight gain $(\mathrm{kg})$. To determine weight gain, the animals were weighed at the beginning of the experiment and then every $7 \mathrm{~d}$ (in the morning, before feed supply) until the final body weight (BW) measurement $(32.2 \pm 0.2 \mathrm{~kg})$ when the lambs were slaughtered. Average daily gain (ADG) was calculated as the ratio between total $\mathrm{BW}$ gain and the duration of the experimental period.

\subsection{Statistical analysis}

The experiment was laid out in a completely randomized design with three treatments $\left(0,100\right.$, and $200 \mathrm{~g} \mathrm{~kg}^{-1} \mathrm{DM}$ of crude glycerin) and 10 replicates each. Results were assessed using analysis of variance and regression, with degrees of freedom decomposed into linear or quadratic effects, according to the percentages of crude glycerin. The significance of the regressions was obtained by an $F$ test at the $1 \%$ or $5 \%$ probability levels using the MIXED procedure of Statistical Analysis System (SAS) version 9.1 (SAS, 2009). 


\section{Results}

The inclusion of crude glycerin in the lambs' diets reduced $(P<0.05)$ the intake of ether extract (EE) 19.3, 10.3, and $4.5 \mathrm{~g}$ and total carbohydrates (TC) $720.0,656.3$, and $576.8 \mathrm{~g}$ to 0,100 , and $200 \mathrm{~g} \mathrm{~kg}^{-1} \mathrm{DM}$ of crude glycerin, respectively. However, there was no effect on the intake of other nutrients (Table 3). Apparent nutrient digestibility was also not altered by the different diets, except for EE digestibility $(P<$ $0.001)$, which was reduced $\left(841.2,736.4\right.$, and $\left.482.6 \mathrm{~g} \mathrm{~kg}^{-1}\right)$ with the increasing levels of dietary crude glycerin (Table 3 ).

The apparent nitrogen balance of the lambs on the three diets was positive and not significantly $(P>0.05)$ different between groups (Table 4). Dietary crude glycerin also had no effect $(P>0.05)$ on nitrogen intake, absorbed nitrogen, or nitrogen excreted in urine and feces.

The lambs performed equally well on diets supplemented with crude glycerin when compared with the controls $(P>$ 0.05 ), with ADGs of $0.264,0.233$, and $0.221 \mathrm{~kg}$ consuming approximately $0.703,0.642$, and $0.613 \mathrm{~kg} \mathrm{~d}^{-1} \mathrm{DM}$ to 0,100 , and $200 \mathrm{~g} \mathrm{~kg}^{-1} \mathrm{DM}$ of crude glycerin, respectively (Table 5). This intake level represented $2.99 \%, 2.74 \%$, and $2.60 \%$ of total BW and a feed conversion of $2.78,2.80$, and 2.82 with the increasing levels of dietary crude glycerin. Although not statistically different $(P>0.05)$, the feedlot days were $68 \mathrm{~d}$ for the lambs that did not receive crude glycerin in their diet, $74 \mathrm{~d}$ for the lambs that received $100 \mathrm{~g} \mathrm{~kg}^{-1} \mathrm{DM}$, and $78 \mathrm{~d}$ for the lambs that received $200 \mathrm{~g} \mathrm{~kg}^{-1} \mathrm{DM}$ (Table 5).

\section{Discussion}

The reduction in the intake and digestibility of EE and the reduction in the intake of TC in the animals fed crude glycerin are directly related to the decreasing concentration of corn in the diets, as glycerin does not contribute to EE and has a lower carbohydrate content (Table 1). In the study of Ribeiro et al. (2018), the authors included 70, 140, and $210 \mathrm{~g} \mathrm{~kg}^{-1} \mathrm{DM}$ of crude glycerin in the diet of lambs and observed a decrease in the intake of NDF and nonfibrous carbohydrates (NFC) and an increase in EE intake. Saleem and Singer (2017) reported a quadratic reduction in the DM intake and a quadratic increase in the DM and EE digestibility of lambs fed with $0 \%, 5 \%$, and $10 \%$ of glycerol replacing corn in their diet. Lage et al. (2010) investigated the inclusion of $0,30,60,90$, and $120 \mathrm{~g} \mathrm{~kg}^{-1} \mathrm{DM}$ of crude glycerin in the diet of feedlot lambs and also reported the influence of glycerin inclusion. In their experiment, there was a $30 \%$ reduction in voluntary DM intake following the addition of $120 \mathrm{~g} \mathrm{~kg}^{-1}$ dietary crude glycerin, which resulted in lower intake of organic matter (OM), CP, NDF, and NFC.

Therefore, why are there differences in the recommendations for crude glycerin inclusion in lamb diets? Perhaps the answer lies in the type of glycerin used. Glycerin has variable levels of glycerol, water, methanol, and fatty acids and is classified as either low purity (50\% to $70 \%$ glyc- erol), medium purity ( $80 \%$ to $90 \%$ glycerol), or high purity (above $99 \%$ glycerol). The low- and medium-purity versions are used in animal nutrition and contain $26.8 \%$ and $1.1 \%$ water, $63.3 \%$ and $85.3 \%$ glycerol, and $26.7 \%$ and $0.04 \%$ methanol, respectively (Südekum, 2008). In addition, the source of fiber, source and amount of starch, and NDF and ADF concentrations in experimental diets can affect nutrient intake and digestibility. For example, Lage et al. (2010) and Ribeiro et al. (2018), like this study, used crude glycerin to replace corn in the lambs' diet, which is the main source of starch. For this reason, there was a reduction in the amount of NFC in the diets with the inclusion of glycerin, with a consequent reduction in the consumption of NFC and/or TC. The amounts of NDF in the animals' diet in our trial were similar, and it is probable that this is the reason that we did not observe differences in the intake of this nutrient. The opposite was reported by the aforementioned authors, who, with the inclusion of crude glycerin in the diet, observed a decrease in the concentration of NDF, with a consequent reduction in the intake and digestibility of this nutrient.

Apparent nitrogen balance constitutes an important tool for determining nitrogen use efficiency by ruminants (Thirumalesh and Krishnamoorthy, 2013). The animals fed crude glycerin maintained a positive nitrogen balance, although with no significant differences when compared with those in the control group. Oliveira Filho et al. (2016) also did not report an influence of the inclusion of crude glycerin $(0,28$, 55,82 , and $108 \mathrm{~g} \mathrm{~kg}^{-1} \mathrm{DM}$ sugarcane silage) on the nitrogen balance of the lambs. This probably occurred because there was equilibrium and synchrony of protein and energy sources in the diets, which meant that the protein : energy ratio did not affect nitrogen retention. Although there was an increase in the glycerol concentration with the inclusion of crude glycerin in the lambs' diet, this increase does not seem to have negatively affected the growth of bacteria and, consequently, nitrogen retention, as when the glycerin quantity was elevated, no differences in the retained nitrogen quantity were observed (Oliveira Filho et al., 2016).

Although there was no statistical difference in animal performance results, we observed worsening performance with the increased inclusion of glycerin in the diet, even with increasing days in the feedlot. The difference in feedlot days between lambs that were not fed glycerin and those that were fed with $200 \mathrm{~g} \mathrm{~kg}^{-1} \mathrm{DM}$ was $10 \mathrm{~d}$. This increase in feedlot days was probably due to a decrease in the DM intake and weight gain. With the inclusion of glycerol in the diet of ruminants, increased propionate in the rumen is observed (Ribeiro et al., 2018); this increases adenosine triphosphate (ATP) production because of its use for glucose production and satiety signaling (Reynolds, 1995) and can contribute to a consequent decrease in the DM intake. Ribeiro et al. (2018) found a decrease in the DM intake, final BW, and ADG of lambs fed diets with glycerin at 70,140 , and $210 \mathrm{~g} \mathrm{~kg}^{-1} \mathrm{DM}$, indicating the inclusion of up to $4.7 \%$ crude glycerin in the diets. According to Schröder and Südekum (2007), glyc- 
Table 3. Intake and digestibility of nutrients of feedlot lambs fed diets containing crude glycerin.

\begin{tabular}{|c|c|c|c|c|c|c|}
\hline \multirow[t]{2}{*}{ Variable } & \multicolumn{3}{|c|}{ Crude glycerin $\left(\mathrm{g} \mathrm{kg}^{-1} \mathrm{DM}\right)$} & \multirow[t]{2}{*}{ SEM $^{\mathrm{a}}$} & \multicolumn{2}{|c|}{$p$ value $^{\mathrm{b}}$} \\
\hline & $\begin{array}{r}0 \\
n=10\end{array}$ & $\begin{array}{r}100 \\
n=10\end{array}$ & $\begin{array}{r}200 \\
n=10\end{array}$ & & $\mathrm{~L}$ & Q \\
\hline \multicolumn{7}{|l|}{ Intake $(\mathrm{g})$} \\
\hline Dry matter & 926.0 & 883.0 & 821.3 & 32.39 & 0.225 & 0.896 \\
\hline Mineral matter & 51.3 & 61.5 & 69.8 & 4.14 & 0.080 & 0.905 \\
\hline Crude protein & 160.5 & 154.0 & 142.5 & 6.90 & 0.335 & 0.874 \\
\hline Ether extract ${ }^{c}$ & 19.3 & 10.3 & 4.5 & 1.91 & $<0.001$ & 0.243 \\
\hline Neutral detergent fiber & 243.5 & 221.8 & 215.5 & 7.56 & 0.154 & 0.631 \\
\hline Acid detergent fiber & 95.8 & 93.5 & 93.3 & 3.63 & 0.804 & 0.909 \\
\hline Total carbohydrates ${ }^{\mathrm{d}}$ & 720.0 & 656.3 & 576.8 & 29.08 & 0.048 & 0.888 \\
\hline Nonfibrous carbohydrates & 535.3 & 489.8 & 435.0 & 22.55 & 0.081 & 0.919 \\
\hline Apparent digestibility of nutrients $\left(\mathrm{g} \mathrm{kg}^{-1}\right)$ & $n=5$ & $n=5$ & $n=5$ & & & \\
\hline Dry matter & 783.3 & 775.6 & 795.2 & 0.57 & 0.409 & 0.283 \\
\hline Crude protein & 752.9 & 739.6 & 754.4 & 0.71 & 0.944 & 0.403 \\
\hline Ether extract ${ }^{\mathrm{e}}$ & 841.2 & 736.4 & 482.6 & 4.91 & $<0.001$ & 0.122 \\
\hline Neutral detergent fiber & 558.0 & 531.2 & 571.8 & 1.71 & 0.762 & 0.402 \\
\hline Acid detergent fiber & 402.7 & 409.8 & 457.8 & 3.47 & 0.563 & 0.802 \\
\hline Total carbohydrates & 809.0 & 797.4 & 807.2 & 0.51 & 0.892 & 0.374 \\
\hline Nonfibrous carbohydrates & 922.5 & 902.1 & 928.6 & 0.61 & 0.672 & 0.081 \\
\hline
\end{tabular}

${ }^{\mathrm{a}}$ SEM is the standard error of the mean. ${ }^{\mathrm{b}}$ The effects are denoted as follows: $\mathrm{L}-$ linear and $\mathrm{Q}-$ quadratic. $^{\mathrm{c}} Y=18.708-0.737 x$,

$r^{2}=0.98 .{ }^{\mathrm{d}} Y=722.625-7.162 x, r^{2}=0.99 .{ }^{\mathrm{e}} Y=86.601-1.792 x, r^{2}=0.94 . n$ denotes the number of lambs per treatment.

Table 4. Apparent nitrogen balance (ANB) in feedlot lambs fed diets containing crude glycerin.

\begin{tabular}{|c|c|c|c|c|c|c|}
\hline \multirow[t]{2}{*}{ Variable } & \multicolumn{3}{|c|}{ Crude glycerin $\left(\mathrm{g} \mathrm{kg}^{-1} \mathrm{DM}\right)$} & \multirow[t]{2}{*}{$\mathrm{SEM}^{\mathrm{a}}$} & \multicolumn{2}{|c|}{$p$ value $^{\mathrm{b}}$} \\
\hline & $n=5$ & $\begin{array}{r}100 \\
n=5\end{array}$ & $\begin{array}{r}200 \\
n=5\end{array}$ & & $\mathrm{~L}$ & Q \\
\hline \multicolumn{7}{|l|}{$\mathrm{N}$ intake } \\
\hline Grams per animal per day & 25.2 & 24.7 & 22.8 & 1.11 & 0.434 & 0.808 \\
\hline Grams per metabolic weight per day & 2.3 & 2.3 & 2.1 & 0.10 & 0,438 & 0.766 \\
\hline \multicolumn{7}{|l|}{ Fecal N } \\
\hline Grams per animal per day & 6.4 & 6.5 & 5.5 & 0.35 & 0.346 & 0.513 \\
\hline Grams per metabolic weight per day & 0.6 & 0.6 & 0.5 & 0.03 & 0.360 & 0.464 \\
\hline Grams per kilogram $\mathrm{N}$ intake & 252.7 & 260.4 & 242.2 & 0.86 & 0.650 & 0.522 \\
\hline \multicolumn{7}{|l|}{ Urinary $\mathrm{N}$} \\
\hline Grams per animal per day & 0.8 & 0.8 & 0.8 & 0.06 & 0.913 & 0.879 \\
\hline Grams per metabolic weight per day & 0.1 & 0.1 & 0.1 & 0.01 & 0.861 & 0.919 \\
\hline Grams per kilogram $\mathrm{N}$ intake & 33.3 & 33.4 & 34.9 & 0.27 & 0.829 & 0.916 \\
\hline \multicolumn{7}{|l|}{ Urinary $\mathrm{N}$} \\
\hline Grams per animal per day & 19.3 & 18.2 & 17.3 & 0.85 & 0.390 & 0.940 \\
\hline Grams per metabolic weight per day & 1.8 & 1.7 & 1.6 & 0.08 & 0.392 & 0.972 \\
\hline Grams per kilogram $\mathrm{N}$ intake & 76.9 & 74.0 & 75.8 & 1.03 & 0.684 & 0.320 \\
\hline \multicolumn{7}{|l|}{ Retained N or ANB } \\
\hline Grams per animal per day & 18.0 & 17.4 & 16.6 & 0.83 & 0.522 & 0.967 \\
\hline Grams per metabolic weight per day & 1.7 & 1.6 & 1.5 & 0.08 & 0.518 & 0.929 \\
\hline Retained N/N intake & 71.4 & 70.6 & 72.3 & 0.84 & 0.696 & 0.537 \\
\hline Retained N/Absorbed N & 93.8 & 95.4 & 95.4 & 0.56 & 0.277 & 0.503 \\
\hline
\end{tabular}

a SEM is the standard error of the mean. ${ }^{\mathrm{b}}$ The effects are denoted as follows: $\mathrm{L}-$ linear and $\mathrm{Q}$ - quadratic. $n$ denotes the number of lambs per treatment. 
Table 5. Performance of feedlot lambs fed diets containing crude glycerin.

\begin{tabular}{|c|c|c|c|c|c|c|}
\hline \multirow[t]{2}{*}{ Variable } & \multicolumn{3}{|c|}{ Crude glycerin $\left(\mathrm{g} \mathrm{kg}^{-1} \mathrm{DM}\right)$} & \multirow[t]{2}{*}{ SEM $^{\mathrm{a}}$} & \multicolumn{2}{|c|}{$p$ value $^{\mathrm{b}}$} \\
\hline & $\begin{array}{r}0 \\
n=10\end{array}$ & $\begin{array}{r}100 \\
n=10\end{array}$ & $\begin{array}{r}200 \\
n=10\end{array}$ & & $\mathrm{~L}$ & Q \\
\hline Initial body weight (kg) & 15.12 & 15.02 & 15.12 & 0.03 & 0.998 & 0.242 \\
\hline Final body weight (kg) & 32.32 & 32.18 & 32.24 & 0.04 & 0.382 & 0.211 \\
\hline Days in feedlot & 68 & 74 & 78 & 2.80 & 0.370 & 0.895 \\
\hline \multicolumn{7}{|l|}{ DM intake } \\
\hline Kilograms per day & 0.703 & 0.642 & 0.613 & 0.02 & 0.109 & 0.740 \\
\hline Percent BW & 2.99 & 2.74 & 2.60 & 0.07 & 0.111 & 0.766 \\
\hline Grams per metabolic weight per day & 65.79 & 60.23 & 57.33 & 1.45 & 0.112 & 0.761 \\
\hline $\mathrm{ADG}^{\mathrm{c}}(\mathrm{kg})$ & 0.264 & 0.233 & 0.221 & 0.01 & 0.193 & 0.744 \\
\hline $\mathrm{FC}^{\mathrm{d}}$ ( $\mathrm{kg} \mathrm{DM} \mathrm{kg}^{-1}$ weight gain) & 2.78 & 2.80 & 2.82 & 0.09 & 0.904 & 0.981 \\
\hline
\end{tabular}

${ }^{a}$ SEM is the standard error of the mean. ${ }^{b}$ The effects are denoted as follows: L- linear and Q- quadratic. ${ }^{c}$ ADG is the average daily gain. ${ }^{\mathrm{d}} \mathrm{FC}$ is the feed conversion. $n$ denotes the number of lambs per treatment.

erin with different degrees of purity can be included up to $10 \% \mathrm{DM}$ in ruminant diets without compromising feed intake or the digestibility of feed components. The results observed in our study suggest the possible inclusion of up to $200 \mathrm{~g} \mathrm{~kg}^{-1} \mathrm{DM}$ of crude glycerin in lambs' diets, as there were no statistical differences between the treatments in the performance, nitrogen balance, intake, and digestibility of most nutrients evaluated. However, the 10 extra days in the feedlot for lambs fed $200 \mathrm{~g} \mathrm{~kg}^{-1} \mathrm{DM}$ crude glycerin need to be considered.

\section{Conclusions}

Crude glycerin is an efficient alternative to corn in the diet of feedlot lambs fed with sugarcane as roughage. Although it does not affect the intake and digestibility of most nutrients, the inclusion of 100 and $200 \mathrm{~g} \mathrm{~kg}^{-1} \mathrm{DM}$ of crude glycerin in the diet tends to worsen lamb performance, indicating that the ideal level of inclusion should be below $100 \mathrm{~g} \mathrm{~kg}^{-1} \mathrm{DM}$ of crude glycerin.

Data availability. The original data used in this study are available from the corresponding author upon request.

Author contributions. AGSS designed the study, analyzed the data, and drafted and revised the paper. FAM, THB, LGAC, and NMBLZ designed the study, collected and analyzed the data, and drafted and revised the paper. RLV, FAA, VE, and CRV collected and analyzed the data, and drafted and revised the paper. All authors contributed to refining the text and approved the final version of the paper.

Competing interests. The authors declare that they have no conflict of interest.
Disclaimer. Publisher's note: Copernicus Publications remains neutral with regard to jurisdictional claims in published maps and institutional affiliations.

Financial support. This research has been supported by the Fundação de Amparo a Pesquisa do Estado de Sao Paulo (FAPESP; grant no. 2012/25250-7).

Review statement. This paper was edited by Manfred Mielenz and reviewed by two anonymous referees.

\section{References}

AOAC: Official methods of analysis, 16th Edn., Association of official analytical chemicals, Washington, DC, USA, 1998.

Bligh, E. G. and Dyer, W. J.: A rapid method of total lipid extraction and purification, Can. J. Biochem. Phys., 37, 911-917, 1959.

Borghi, T. H., Silva Sobrinho, A. G., Zeola, N. M. B. L., Almeida, F. A., Cirne, L. G. A., and Lima, A. R. C.: Dietary glycerin does not affect meat quality of Ile de France lambs, Rev. Bras. Zootecn., 45, 554-562, https://doi.org/10.1590/S1806$92902016000900008,2016$.

Endo, V., Silva Sobrinho, A. G., Almeida, F. A., Lima, N. L. L., and Zeola, N. M. B. L.: Digestibility and nitrogen balance of lambs fed sugarcane hydrolyzed under different conditions as roughage in the diet, Cienc. Rural, 45, 304-310, https://doi.org/10.1590/0103-8478cr20131679, 2015.

Gunn, P. J., Schultz, A. F., Van Emon, M. L., Neary, M. K., Lemenager, R. P., Rusk, C. P., and Lake, S. L.: Effects of elevated crude glycerin concentrations on feedlot performance, carcass characteristics and serum metabolite and hormone concentrations in finishing ewe and wether lambs, The Professional Animal Scientist, 26, 298-306, https://doi.org/10.15232/S1080-7446(15)30597-0, 2010. 
Hartman, L. and Lago, R. C. A.: Rapid preparation of fatty acid methyl esters from lipids, Laboratory Practice, 22, 475-476, 1973.

Krehbiel, C. R.: Ruminal and physiological metabolism of glycerin, J. Anim. Sci., 86, E-Suppl., Abstr. 392, 2008.

Lage, J. F., Paulino, P. V. R., Pereira, L. G. R., Valadares Filho, S. C., Oliveira, A. S., Detmann, E., Souza, N. K. P., and Lima, J. C. M.: Crude glycerin on finishing lamb diets, Pesq. Agropec. Bras., 45, 1012-1020, https://doi.org/10.1590/S0100204X2010000900011, 2010.

NRC (National Research Council, Ed.): Nutrient Requirements of Small Ruminants: Sheep, Goats, Cervids and New World Camelids, The National Academy Press, Washington, DC, 2007.

Oliveira Filho, C. A. A., Azevêdo, J. A. G., Carvalho, G. G. P., Silva, C. F. P. G., Cabral, Í. S., Pereira, L. G. R., Reis, L. G., Almeida, F. M., and Souza, L. L.: Crude glycerin combined with sugar cane silage in lamb diets, Trop. Anim. Health Pro., 48, 289-295, https://doi.org/10.1007/s11250-015-0948-7, 2016.

Reynolds, C. K.: Quantitative aspects of liver metabolism in ruminants, in: Ruminant physiology: digestion, metabolism, growth, and reproduction, edited by: Englehardt, W. V., LeonhardMarek, S., and Breves, G., Ferdinand Enke Verlag, Stuttgart, 351-372, 1995.

Ribeiro, R. D. X., Carvalho, G. G. P., Silva, T. M., Costa, J. B., Bezerra, L. R., Cambuí, G. B., Barbosa, A. M., and Oliveira, R. L.: Effects of crude glycerin from biodiesel on the diets of lambs: intake, digestibility, performance, feeding behavior, and serum metabolites, J. Anim. Sci., 96, 1952-1961, 2018.
Saleem, A. M. and Singer, A. M.: Growth performance and digestion of growing lambs fed diets supplemented with glycerol, Animal, 12, 959-963, https://doi.org/10.1017/S1751731117001793, 2017.

SAS (Statistical Analysis System, Ed.): Version 9.1, SAS Institute Inc, Cary, NC, 2009.

Schröder, A. and Südekum, K. H.: Glycerol as a byproduct of biodiesel production in diets of ruminants. Institute of Animal Nutrition, Physiology and Metabolism, University of Kiel, Kiel, available at: http://www.regional.org.au/au/gcirc/1/241.htm (last access: 1 September 2020), 2007.

Sniffen, C. J., Connor, J. D., and Van Soest, P. J.: A net carbohydrate and protein system for evaluation cattle diets. II Carbohydrate and protein availability, J. Anim. Sci., 70, 3562-3577, https://doi.org/10.2527/1992.70113562x, 1992.

Südekum, K. H.: Co-products from biodiesel production, in: Recent advances in animal nutrition, edited by: Garnsworthy, P. C. and Wiseman, J., Nottingham University Press, Nottingham, 210 219, 2008.

Thirumalesh, T. and Krishnamoorthy, U.: Rumen Microbial Biomass Synthesis and Its Importance in Ruminant Production, International Journal of Livestock Research, 3, 5-26, https://doi.org/10.5455/ijlr.20130502081346, 2013.

Van Soest, P. J.: Nutritional ecology of the ruminant, Cornell University Press, Ithaca, 1994. 